\title{
Vliv Jaderné elektrárny Temelín na obsah vybraných radionuklidů v povrchových vodách
}

\section{DIANA MAREŠOVÁ, EVA JURANOVÁ, BARBORA SEDLÁŘOVÁ}

\author{
Klíčová slova: radionuklidy - cesium 137 - stroncium 90 - tritium - povrchová voda - odpadní voda
}

\section{SOUHRN}

V př́spěvku jsou prezentovány výsledky dlouhodobého sledování radionuklidů cesia 137, stroncia 90 a tritia v povrchové vodě v okolí Jaderné elektrárny Temelín (dále jen JE Temelín). Tyto radionuklidy pochází především z reziduálního znečištění po atmosférických testech jaderných zbraní a havárii jaderného reaktoru v Černobylu v minulém století. Na všech lokalitách byl pozorován pokles objemových aktivit cesia 137 a stroncia 90. I přesto, že velká část hodnot koncentrací těchto radionuklidů je v současnosti na úrovni nejmenších detekovatelných aktivit, stále je reziduální kontaminace vyšší než jsou výpusti těchto radionuklidů, resp. aktivačních a štěpných produktů, z JE Temelín. V případě tritia byl v profilech neovlivněných provozem JE pozorován pomalý pokles objemových aktivit, které se bliží přirozenému pozadí odpovídajícímu geografickým podmínkám České republiky. V profilech ovlivněných provozem JE Temelín byl pozorován postupný nárůst aktivit tritia, odpovídající výpustem udávaných provozovatelem. Zjištěné objemové aktivity hodnocených radionuklidů vyhovují požadavkům nařízení vlády 401/2015 Sb. v ukazatelích radioaktivních látek.

\section{ÚVOD}

V souvislosti s výstavbou a provozem JE Temelín byla realizována řada projektů zabývajících se možnými vlivy provozu elektrárny na životní prostředí. Na projekty z předprovozního období [1,2] následně navázal zejména Program sledování a hodnocení vlivu Jaderné elektrárny Temelín na životní prostředí [3]. Provoz každé jaderné elektrárny je doprovázen produkcí radionuklidů, z toho důvodu je v rámci sledování velká pozornost věnována výskytu vybraných radionuklidů $v$ okolí jaderné elektrárny. Tento príspěvek se zaměřuje na zhodnocení vlivu JE Temelín na obsah vybraných radionuklidů - cesia 137, stroncia 90 a tritia - v povrchových vodách v období 1990-2019 na základě sledování citovaných výše [1-3].

Výstavba JE Temelín byla schválena již v roce 1980, vlastní realizace byla zahájena v roce 1987. Z původně plánovaných čtyř bloků byly postaveny dva. Jedná se o tlakovodní reaktory VVER 1000 typu V 320. Výroba elektřiny byla zahájena v závěru roku 2000. Aktuálně elektrárna pracuje na výkonu 2 × 1082 MWe [4]. V současnosti je zvažována výstavba nového jaderného zdroje $v$ lokalitě Temelín [5]. JE Temelín odebírá surovou vodu z vodní nádrže Hněvkovice a odpadní vody vypouští přes vodní nádrž Kořensko. Ve světě jsou odpadní vody z jaderných zařizení obvykle vypouštěny do velkých řek, prípadně do moře. Ve srovnání s řekami, jako jsou např. Dunaj nebo Rýn, je Vltava v místě zaústění odpadních vod z JE Temelín poměrně malý tok. Vzhledem k očekávaným klimatickým změnám včetně zvýšeného výskytu hydrologického sucha se Ize obávat možného nárůstu objemových aktivit radionuklidů pod zaústěním odpadních vod. Proto je jejich sledování věnována velká pozornost.

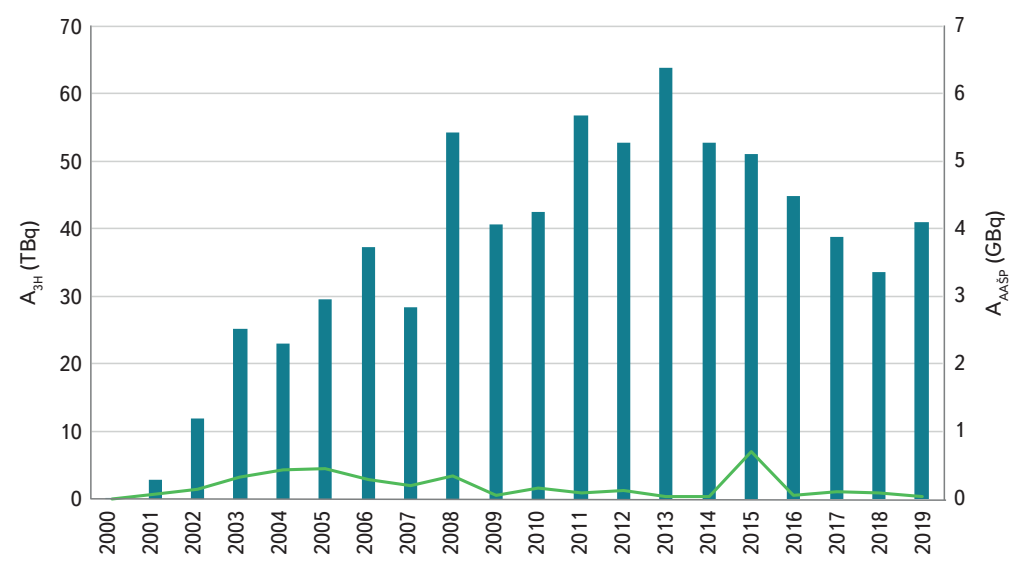

$3 \mathrm{H}$

Obr. 1. Roční výpusti ${ }^{3} \mathrm{H}$ a AAŠP podle ČEZ, a. s., JETE $[8,9]$

Fig. 1. Annual discharges of ${ }^{3} \mathrm{H}$ and activation and fission products according ČEZ, a. S., JETE $[8,9]$

Tritium $\left({ }^{3} \mathrm{H}\right)$, cesium $137\left({ }^{137} \mathrm{Cs}\right)$ a stroncium $90\left({ }^{90} \mathrm{Sr}\right)$ jsou nejvýznamnější radionuklidy potenciálně prítomné $v$ odpadních vodách. Tritium je radioaktivní izotop vodíku s poločasem rozpadu 12,32 r, který se přirozeně vyskytuje v množství 1 atom na $10^{18}$ atomů vodíku [6]. V prírodě vzniká především v horních vrstvách atmosféry pưsobením kosmického záření. Vzniká i při umělých jaderných reakcích, stejně jako cesium 137 a stroncium 90, které jsou radioekologicky významné vzhledem k poločasu rozpadu 30,2 r, resp. 28,8 r [7]. Roční kapalné výpusti tritia a ostatních aktivačních a štěpných produktů (AAŠP), mezi které patř́i i ${ }^{1{ }^{13}} \mathrm{Cs}$ a ${ }^{90} \mathrm{Sr}$, podle ČEZ, a. S., [8, 9] jsou uvedeny na obr. $1 . Z$ údajů vyplývá, že roční výpusti ${ }^{3} \mathrm{H}$ jsou v rádu desítek TBq $\left(\mathrm{TBq}=10^{12} \mathrm{~Bq}\right)$, v období 2000-2019 v průměru $40 \mathrm{TBq} \cdot \mathrm{r}^{\mathrm{r}}$.

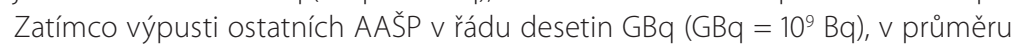
$0,2 \mathrm{GBq} \cdot r^{\prime}$, výpusti ${ }^{137} \mathrm{Cs}$ a ${ }^{90} \mathrm{Sr}$ jsou tedy více než o pět rádư menší než výpusti tritia. Z radioekologického hlediska je tedy v kapalných výpustích při běžném provozu nejvýznamnějším radionuklidem tritium. Pro posouzení vlivu výpustí na obsah hodnocených radionuklidů $v$ povrchových vodách je významným faktem to, že odpadní vody s obsahem radionuklidů jsou po kontrolních měřeních vypouštěny diskontinuálně, v průměru asi 3-4 hodiny denně.

Hodnocené radionuklidy se $v$ okolí JE Temelín vyskytovaly ještě před jejím spuštěním. Důvodem je doznívající znečištění po testech jaderných zbraní $\checkmark$ padesátých a šedesátých letech minulého století a havárii jaderného reaktoru v Černobylu v roce 1986. Okolí JE Temelín patří mezi oblasti u nás nejvíce zasažené spadem po havárii v Černobylu [10]. V prípadě tritia se jedná i o jeho přirozený výskyt. I proto měly velký význam studie, které se uskutečnily ještě před uvedením JE Temelín do provozu, a které zjištovaly referenční stav [1, 2]. 
Dřivější výsledky citovaných studií byly prezentovány např. [11-13]. Hlavním cílem prríspěvku je prezentovat aktuální výsledky nyní téměř třicetiletého sledování výskytu vybraných radionuklidů v řece Vltavě ovlivněné provozem JE Temelín a zhodnotit prípadný príspěvek elektrárny.

\section{METODIKA}

Radionuklidy ${ }^{3} \mathrm{H},{ }^{90} \mathrm{Sr}$ a ${ }^{137} \mathrm{Cs}$ byly stanovovány v povrchové vodě ve veškerých látkách. Sledování bylo zahájeno v roce 1990 na profilech Vltava-Hněvkovice, Lužnice-Koloděje, Otava-Písek (později změněn na profil Otava-Topělec, hodnocení je pod tímto označením) - profily $\vee$ budoucnu prímo neovlivněné výpustmi odpadních vod z JE Temelín, dále označované pouze jako neovlivněné profily, a Vltava-Solenice - profil v budoucnu ovlivněný výpustmi JE Temelín. Od roku 1996 bylo sledování rozšířeno o profil Vltava-Hladná, profil cca 4 km pod zaústěním odpadních vod. Mapa odběrových míst je na obr. 2.

Vzorky byly odebírány podle norem ČSN EN ISO 5667 a ČSN ISO 5667 (soubor) [14-17] v množství 0,25 I ( $\left.{ }^{3} \mathrm{H}\right)$, resp. 50 I $\left({ }^{137} \mathrm{Cs}\right.$ a $\left.{ }^{90} \mathrm{Sr}\right)$, frekvence odběrů byla čtvrtletní. Vzorky na stanovení ${ }^{3} \mathrm{H}$ byly konzervovány chlazením. Velkoobjemové vzorky pro stanovení ${ }^{137} \mathrm{Cs}$ a ${ }^{90} \mathrm{Sr}$ byly stabilizovány okyselením kyselinou dusičnou na $\mathrm{pH}<2$ a přidáním směsného nosiče. V laboratoři byly vzorky odpařeny pod bodem varu do sucha, následně byly vysušeny při $105^{\circ} \mathrm{C}$ a vyžíhány při $350^{\circ} \mathrm{C}$. Vyžíhaný odparek byl uzavřen do príslušné měřicí nádoby. Stanovení ${ }^{137} \mathrm{Cs}$ a ${ }^{90} \mathrm{Sr}$ tedy postihuje veškeré látky.

Stanovení objemové aktivity tritia bylo uskutečněno podle ČSN EN ISO 9698 [18]. Pro stanovení byly použity nízkopozad’vé kapalinové scintilační spektrometry Quantulus 1220 od firmy WALLAC a TriCarb 3170/TRSL od firmy Canberra Packard. Podmínky měření vzorků z lokalit ovlivněných výpustmi z JE Temelín byly nastaveny tak, aby pro tritium byla nejmenší detekovatelná aktivita $\left(\mathrm{C}_{\mathrm{ND}}\right)$ cca $2 \mathrm{~Bq} / \mathrm{l}$, v prípadě neovlivněných vzorků cca $1 \mathrm{~Bq} \cdot \mathrm{I}^{-1}$.

Ve velkoobjemových vzorcích vod po předúpravě bylo nejdřive gamaspektrometricky stanoveno ${ }^{137} \mathrm{Cs}$ (podle ČSN EN ISO 10703 [19]) a následně bylo radiochemicky analyzováno ${ }^{90} \mathrm{Sr}$ [20]. Pro stanovení ${ }^{137} \mathrm{Cs}$ byla použita gamaspektrometrická trasa s polovodičovým germaniovým detektorem REGe fy Canberra Packard. Nejmenší detekovatelná objemová aktivita $\left(\mathrm{C}_{\mathrm{ND}}\right)$ pro ${ }^{137} \mathrm{Cs}$ na hladině významnosti chyb pozorování prvního a druhého typu $a=\beta=0,05$ byla v závislosti na době měření a množství zpracovaného vzorku cca $0,5 \mathrm{mBq} \cdot \mathrm{\cdot}^{-1}$. Stanovení ${ }^{90} \mathrm{Sr}$ bylo provedeno štavelanovou srážecí metodou [20]. Pro měření aktivity byl použit proporcionální detektor fy TESLA s vyhodnocovací jednotkou MC 2256, později alfa - beta automat EMS 3 s plynovou průtočnou sondou POB 302 fy EMPOS. Nejmenší detekovatelná objemová aktivita $\left(c_{\mathrm{ND}}\right)$ na hladině významnosti $a=\beta=0,05$ byla pro ${ }^{90} \mathrm{~S} r v$ závislosti na době měření a množství zpracovaného vzorku a chemického výtěžku cca $2 \mathrm{mBq} \cdot{ }^{1-1}$.

$\checkmark$ prípadě hodnot menších než nejmenší detekovatelná objemová aktivita byl pro jejich další zpracování aplikován postup podle směrnice Komise 2009/90/ES, resp. Nesměráka [21]. Byl použit redukční koeficient $k=0,5$, tj. byla použita hodnota rovná $0,5 \mathrm{C}_{\mathrm{ND}}$.

Pro hodnocení vývoje objemových aktivit radionuklidů v čase byla použita regresní analýza rovnice vycházející úpravou rovnice (1) pro radioaktivní přeměnu:

$$
\ln C_{t}=-\lambda_{e f} \cdot t+\ln C_{0}
$$

kde $C_{t}$ je objemová aktivita radionuklidu v čase $t\left(B q \cdot \cdot^{-1}\right)$,

$\lambda_{\text {ef }}^{t}$ efektivní (pozorovaná) přeměnová konstanta, získaná jako směrnice prímky poklesu $\left(r^{1}\right)$,

$t \quad$ čas $(r)$,

$C_{0} \quad$ objemová aktivita radionuklidu v čase $t=0\left(\mathrm{~Bq} \cdot \mathrm{I}^{-1}\right)$.
Statistická významnost regresní křivky byla ověřena pomocí Pearsonova koeficientu. Následně byl vypočten efektivní (pozorovaný) poločas radionuklidu $T_{\text {ef }}(r)$ podle rovnice (2) [22]:

$$
T_{e f}=\frac{\ln 2}{\lambda_{e f}}
$$

Roční bilance aktivity (B) radionuklidu v profilu $\left(\mathrm{Bq} \cdot \mathrm{r}^{\mathrm{r}}\right.$ ) byla vypočtena podle rovnice (3):

$$
B_{j}=C_{j} \cdot Q_{j} \cdot t
$$

kde $C_{j}$ je roční průměrná objemová aktivita radionuklidu v profilu j $\left(\mathrm{Bq} \cdot \mathrm{m}^{-3}\right)$, $Q_{j} \quad$ roční průměrný průtok $v$ profilu $j v$ roce $\left(m^{3} \cdot s^{-1}\right)$,

t doba trvání 1 roku $\left(s \cdot r^{-1}\right)$.

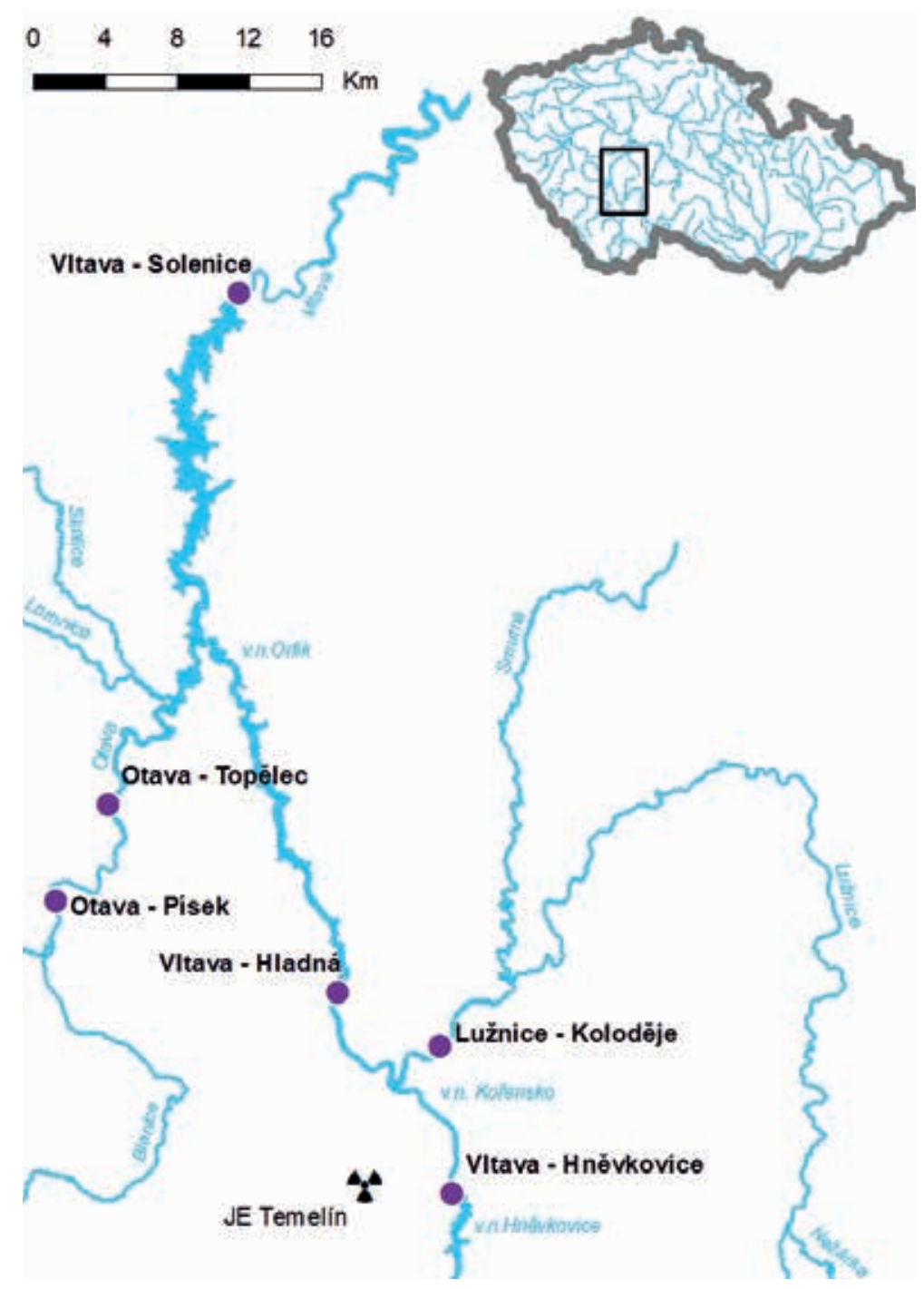

Obr. 2. Mapa odběrových profilů

Fig. 2. Map of the sampling sites 


\section{VÝSLEDKY A DISKUSE}

Nejdéle sledovaným radionuklidem je ${ }^{137} C$ s, které je $v$ hodnocených profilech sledováno od roku 1990. Vývoj objemové aktivity ${ }^{137} \mathrm{Cs}$ je znázorněn na obr. 3. Pro ukázku je uveden vážený průměr ročních průměrných objemových aktivit $v$ neovlivněných profilech - Vltava-Hněvkovice, Lužnice-Koloděje, OtavaTopělec a roční průměrné objemové aktivity v profilu Vltava-Solenice ovlivněném výpustmi z JE Temelín.

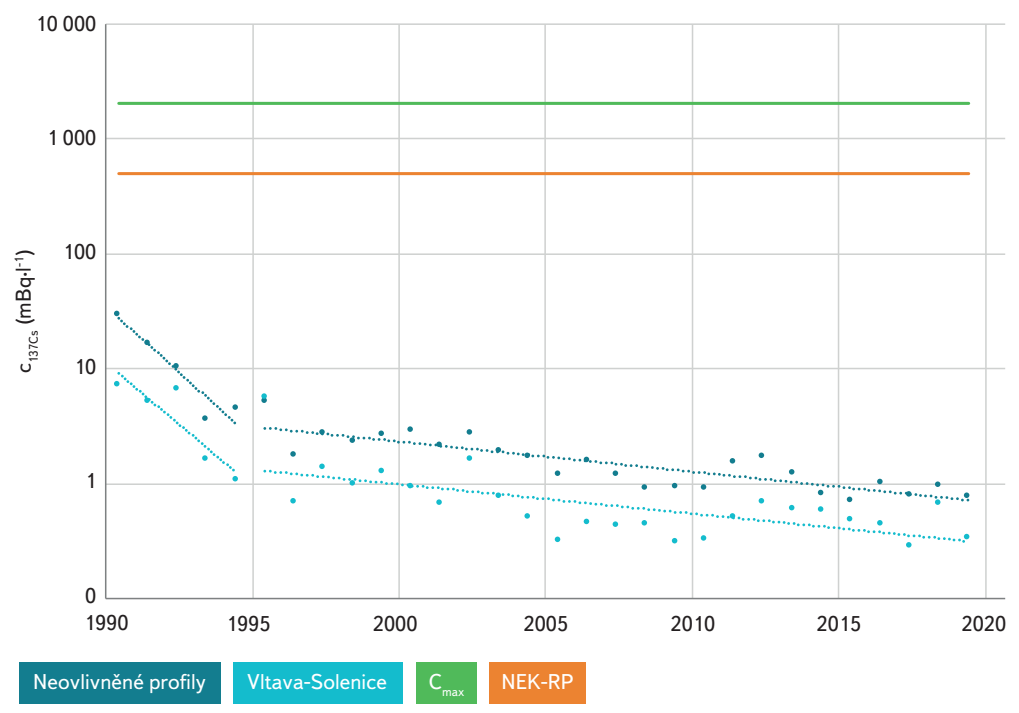

Obr. 3. Vývoj objemové aktivity ${ }^{137} \mathrm{Cs}\left(\mathrm{C}_{137 c s}\right)$ v profilech neovlivněných výpustmi z JE Temelín, v ovlivněném profilu VItava-Solenice a hodnota prípustného znečištění $C_{\max }$ a NEK-RP podle NV 401/2015 Sb. [23]

Fig. 3. Temporal changes of ${ }^{137} \mathrm{Cs}$ concentration $\left(\mathrm{C}_{137 \mathrm{c}}\right)$ in profiles not effected by discharges from the NPP Temelín, in the VItava River at Solenice (effected profile) and value of permissible pollution $C_{\max }$ and environmental quality standard-annual average NEK-RP according NV 401/2015 Sb. [23]

Z obr. 3 je zřejmé, že zatímco na začátku sledovaného období byly zjištěné roční průměrné objemové aktivity až desítky $\mathrm{mBq} \cdot \mathrm{l}^{-1}, \mathrm{v}$ závěru tohoto období to bylo $<\left.1 \mathrm{mBq}\right|^{-1}$, a to jak na profilech neovlivněných, tak $v$ profilu ovlivněném provozem JE Temelín. Většina hodnot v závěru hodnoceného období byla $<\mathrm{C}_{\mathrm{ND}}$. Zjištěné hodnoty jsou po celou dobu ráádově nižší, než je hodnota přípustného znečištění $c_{\max }=2 \mathrm{~Bq} \cdot \mathrm{l}^{-1}$ i než norma environmentální kvality, roční průměr NEK-RP $=0,5 \mathrm{~Bq} \cdot \mathrm{l}^{-1}$ podle nařízení vlády 401/2015 Sb [23]. V první polovině devadesátých let byl pozorován výrazně rychlejší pokles aktivit. Pro období 1990-1994 byly v jednotlivých profilech vyhodnocené efektivní poločasy ${ }^{137} \mathrm{Cs}$ $\checkmark$ rozmezí 1,1-2,8 r, na neovlivněných profilech to bylo průměrně 1,3 r, v profilu VItava-Solenice 1,4 r (přehled pro všechny profily je uveden $v$ tabulce 1). Jedná se především o doznívající vliv havárie jaderného reaktoru v Černobylu. Po roce 1995 bylo pozorováno zpomalení rychlosti ubývání ${ }^{137}$ Cs. V období 1995-2019 byly pozorované poločasy $v$ rozmezí 9,4-12,4 r. Pro neovlivněné profily to bylo 11,5 r, pro profil VItava-Solenice 12,4 r. Trvalý pokles objemových aktivit pokračoval i po roce 2000, kdy byla uvedena do provozu JE Temelín.

S využitím ročních průměrných koncentrací ${ }^{137} \mathrm{C}$ S a ročních průměrných průtoků vody $v$ príslušném profilu byly podle rovnice (3) vypočteny roční bilance ${ }^{137} \mathrm{Cs}\left(\mathrm{B}_{137 \mathrm{cs}}\right)$ ve sledovaných profilech.

Vypočtené bilance byly porovnány s publikovanými údaji o výpustech AAŠP $[8,9]$. Z podrobnějšího hodnocení byl vyloučen rok 2002, který byl ovlivněn extrémními průtoky. Podrobněji bylo tedy zpracováno období 2003-2019. Průměrná vypočtená bilance v období 1996-2019 (resp. 2003-2019) byla na neovlivněných profilech VItava-Hněvkovice 1,0 GBq·r $r^{-1}$ (resp. 0,6 GBq.r'), Lužnice-Koloděje

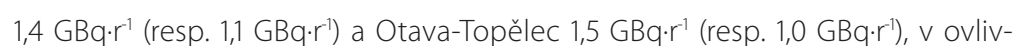
něných profilech Vltava-Hladná 2,8 GBq. $r^{-1}$ (resp. 2,1 GBq.r $r^{-1}$ ) a Vltava-Solenice 1,7 GBq.r $r^{-1}$ (resp. 1,1 GBq $\cdot r^{-1}$ ). V místě zaústění odpadních vod z JE Temelín tedy antropogenní pozadí ${ }^{137}$ Cs v období 2003-2019 vyjádřené jako součet průměrných bilancí v profilech VItava-Hněvkovice a Lužnice-Koloděje bylo 1,7 GBq $\cdot{ }^{-1}$, zatímco průměrná výpust AAŠP v tomto období byla $0,2 \mathrm{GBq} \cdot r^{-1}[8,9]$. Na obr. 4 je zobrazen vývoj „pozadí ${ }^{137} \mathrm{Cs}$ “ v místě zaústění odpadních vod vyjádřeného jako součet bilance ${ }^{137} \mathrm{Cs} \vee$ profilech VItava-Hněvkovice a Lužnice-Koloděje, bilance ${ }^{137} \mathrm{Cs}$ v ovlivněném profilu VItava-Solenice a výpustí AAŠP. I při provozu JE Temelín byly na ovlivněném profilu VItava-Solenice zjištovány po celou dobu menší koncentrace i bilance ${ }^{137} \mathrm{C}$ s než v ovlivněných profilech. Je to způsobeno vazbou ${ }^{137} \mathrm{Cs}$ na nerozpuštěné látky a jejich sedimentací ve vodní nádrži Orlík. Vliv JE Temelín tedy nebyl detekován na žádném profilu, resp. možný vliv je zcela překrytý reziduální kontaminací.

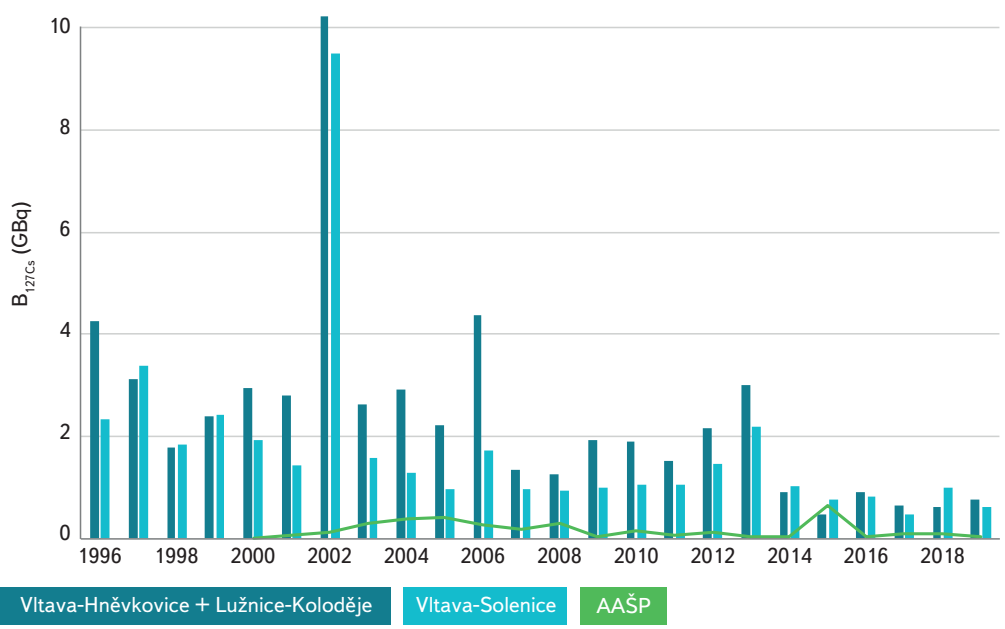

Obr. 4. Vývoj antropogenního pozadí ${ }^{137} \mathrm{Cs} v$ místě zaústění odpadních vod vyjádřeného jako součet bilance ${ }^{137} \mathrm{Cs} v$ profilech VItava-Hněvkovice a Lužnice-Koloděje, bilance ${ }^{137} \mathrm{Cs}$ v ovlivněném profilu VItava-Solenice a výpusti AAŠP podle ČEZ, a. S., JETE $[8,9]$ Fig. 4. Temporal changes of activity ${ }^{137} \mathrm{Cs}$ balances (artificial bacground of ${ }^{137} \mathrm{Cs}$, calculated as a sum of ${ }^{137} \mathrm{Cs}$ balances in the VItava River at Hněvkovice and the Lužnice River at Koloděje), balance at effected in the VItava River at Solenice and discharges of activation and fission products according ČEZ, a. S., JETE [8, 9]

Stanovení ${ }^{90} \mathrm{Sr}$ je prováděno od roku 1993. Vývoj objemové aktivity ${ }^{90} \mathrm{Sr}$ je znázorněn na obr. 5. Je uveden vážený průměr ročních objemových aktivit na neovlivněných profilech a roční průměrné objemové aktivity $v$ profilu VltavaSolenice ovlivněném výpustmi z JE Temelín. Na začátku sledovaného období byly pozorovány roční průměrné objemové aktivity do $10 \mathrm{mBq} \cdot \mathrm{I}^{-1}$, na konci období pak pouze $<2 \mathrm{mBq} \cdot \cdot^{-1}$. Na všech sledovaných profilech byly pozorované hodnoty velmi podobné, jak $v$ profilech neovlivněných, tak $v$ profilu VItava-Solenice ovlivněném provozem JE Temelín. Zjištěné hodnoty jsou tedy po celou dobu řádově nižší než je hodnota přípustného znečištění $C_{\max }=1 \mathrm{~Bq} \cdot \cdot^{-1}$ i norma environmentální kvality roční průměr $\mathrm{NEK}-\mathrm{RP}=0,2 \mathrm{~Bq} \cdot \mathrm{J}^{-1}$ podle nařízení vlády 401/2015 Sb. [23].

Po celé sledované období byl pozorován trvalý pokles ročních průměrných objemových aktivit ${ }^{90} \mathrm{Sr}$. Na rozdíl od ${ }^{137} \mathrm{Cs}$ nebyla zjištěna změna $v$ rychlosti tohoto poklesu. Vyhodnocený efektivní poločas byl na všech profilech shodně cca 10 r (tabulka 1). Tak jako $v$ prípadě ${ }^{137} C$ s byly s využitím ročních průměrných objemových aktivit ${ }^{90} \mathrm{~S}$ r a ročních průměrných průtoků vody v príslušném profilu vypočteny roční bilance ${ }^{90} \mathrm{Sr}\left(\mathrm{B}_{905}\right)$ ve sledovaných profilech. Podrobnější hodnocení bylo provedeno shodně jako v případě ${ }^{137} \mathrm{Cs}-$ bylo hodnoceno období 2003-2019. Prưměrná vypočtená bilance v období 1996-2019, (resp. 2003-2019) byla na neovlivněných profilech Vltava-Hněvkovice 3,6 GBq.r $r^{-1}\left(3,3 \mathrm{GBq} \cdot r^{-1}\right)$, 


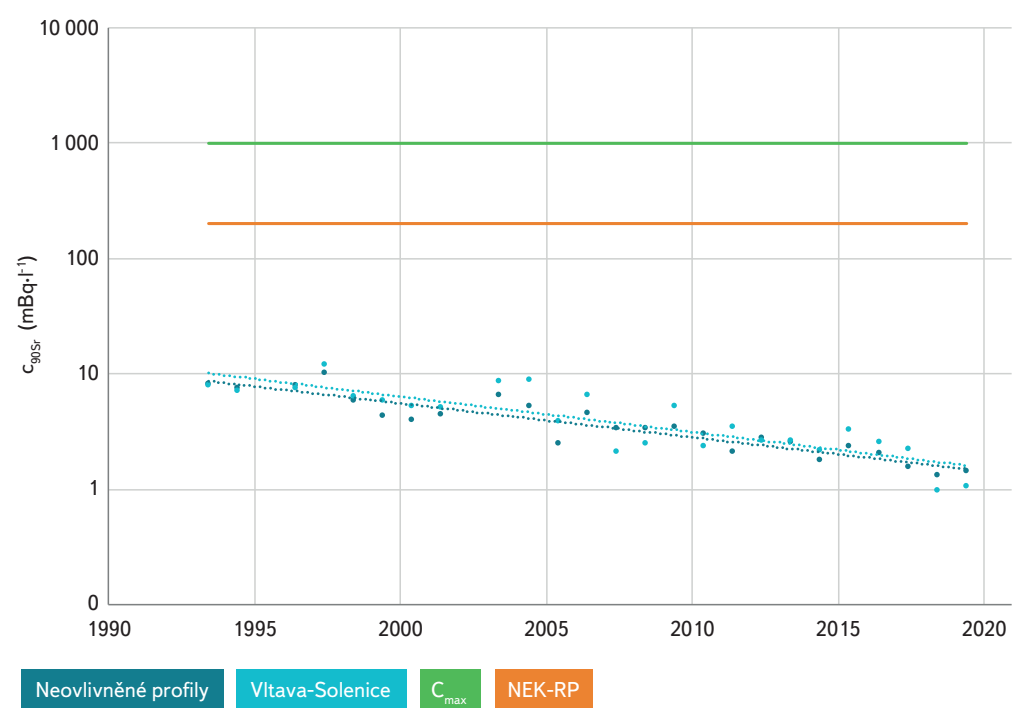

Obr. 5. Vývoj objemové aktivity ${ }^{90} \mathrm{Sr}\left(\mathrm{C}_{905}\right)$ v profilech neovlivněných výpustmi z JE Temelín, v ovlivněném profilu VItava-Solenice a hodnota prípustného znečištění $C_{\max }$ a NEK-RP podle NV 401/2015 Sb. [23]

Fig. 5. Temporal changes of ${ }^{90} \mathrm{Sr}$ concentration $\left(\mathrm{C}_{905 \mathrm{r}}\right)$ in profiles not effected by discharges from the NPP Temelín and in the VItava River at Solenice (effected profile), value of permissible pollution $C_{\max }$ and environmental quality standard-annual average NEK-RP according NV 401/2015 Sb. [23]

Lužnice-Koloděje 3,5 GBq·r $r^{-1}\left(3,1 \mathrm{GBq} \cdot r^{-1}\right)$ a Otava-Topělec 2,4 GBq $\cdot r^{-1}\left(2,2 \mathrm{GBq} \cdot r^{-1}\right)$,

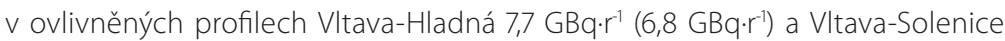
12,1 GBq·r $r^{1}\left(10,9 \mathrm{GBq} \cdot r^{1}\right)$. V místě zaústění odpadních vod z JE Temelín tedy antropogenní pozadí ${ }^{90} \mathrm{Sr}$ v období 2003-2019 vyjádřené jako součet průměrných bilancí v profilech VItava-Hněvkovice a Lužnice-Koloděje bylo 5,1 GBq.r'1, zatímco průměrná výpust AAŠP v tomto období byla $0,2 \mathrm{GBq} \cdot r^{-1}[8,9]$. Na obr. 6 je zobrazen vývoj „pozadí ${ }^{90} \mathrm{Sr}$ “ v místě zaústění odpadních vod vyjádřeného jako součet bilance ${ }^{90} \mathrm{Sr} v$ profilech Vltava-Hněvkovice a Lužnice-Koloděje, bilance ${ }^{90} \mathrm{~S} r$ v ovlivněném profilu VItava-Solenice a výpustí AAŠP. Tak jako v príppadě ${ }^{137} \mathrm{Cs}$ můžeme konstatovat, že vliv JE Temelín v ukazateli ${ }^{90} \mathrm{Sr}$ nebyl detekován na žádném profilu, resp. možný vliv je zcela překrytý reziduální kontaminací.

Sledování tritia bylo v hodnocených profilech zahájeno těsně před uvedením JE Temelín do provozu. Vývoj ročních průměrných objemových aktivit ${ }^{3} \mathrm{H}$ $\checkmark$ neovlivněných profilech a profilech ovlivněných provozem elektrárny je znázorněn na obr.7.

Před spuštěním JE Temelín byla průměrná roční objemová aktivita ve všech profilech shodně cca 1,5 Bq. ${ }^{-1}$, od jejího spuštění je vidět postupné navyšování objemových aktivit ${ }^{3} \mathrm{H}$ v ovlivněných profilech, zatímco na neovlivněných profilech je pozorován mírný, ale trvalý pokles zjištěných aktivit. Na konci hodnoceného období (2019) byla průměrná objemová aktivita v neovlivněných profilech $<1 \mathrm{~Bq} \cdot \mathrm{I}^{-1}$ (většina hodnot byla $<\mathrm{C}_{\mathrm{ND}}$ ), $\vee$ profilu VItava-Hladná to bylo približně $13 \mathrm{~Bq} \cdot \mathrm{l}^{-1}$ a v profilu Solenice $20 \mathrm{~Bq} \cdot \mathrm{l}^{-1}$. V profilu VItava-Hladná měly zjištěné objemové aktivity (jak okamžité, tak roční průměrné) výrazně větší rozpětí hodnot než v profilu Vltava-Solenice. Zjištěné hodnoty jsou po celou dobu nižší, než je hodnota prípustného znečištění $C_{\max }=3500 \mathrm{~Bq} \cdot \mathrm{l}^{-1}$ i norma environmentální kvality roční průměr NEK-RP $=1000 \mathrm{~Bq} \cdot \mathrm{I}^{-1}$ a $v$ profilu VItava-Solenice, $\mathrm{kde}$ je relevantní i hodnocení, zda povrchová voda vyhovuje užívání pro úpravu na vodu pitnou, i prípustné znečištění roční průměr $C_{R P}=100 \mathrm{~Bq} \cdot{ }^{\mid-1}$ podle nařízení vlády 401/2015 Sb. [23].

I v prípadě ${ }^{3} \mathrm{H}$ byly porovnány bilance $\left(B_{3 H}\right)$ v hodnocených profilech vypočtené na základě ročních průměrných objemových aktivit a ročních průměrných průtoků vody, které byly porovnány s údaji o kapalných výpustech ${ }^{3} \mathrm{H}$ z JE Temelín. Zatímco průměrné pozadí ${ }^{3} \mathrm{H}$ (souhrnně antropogenního

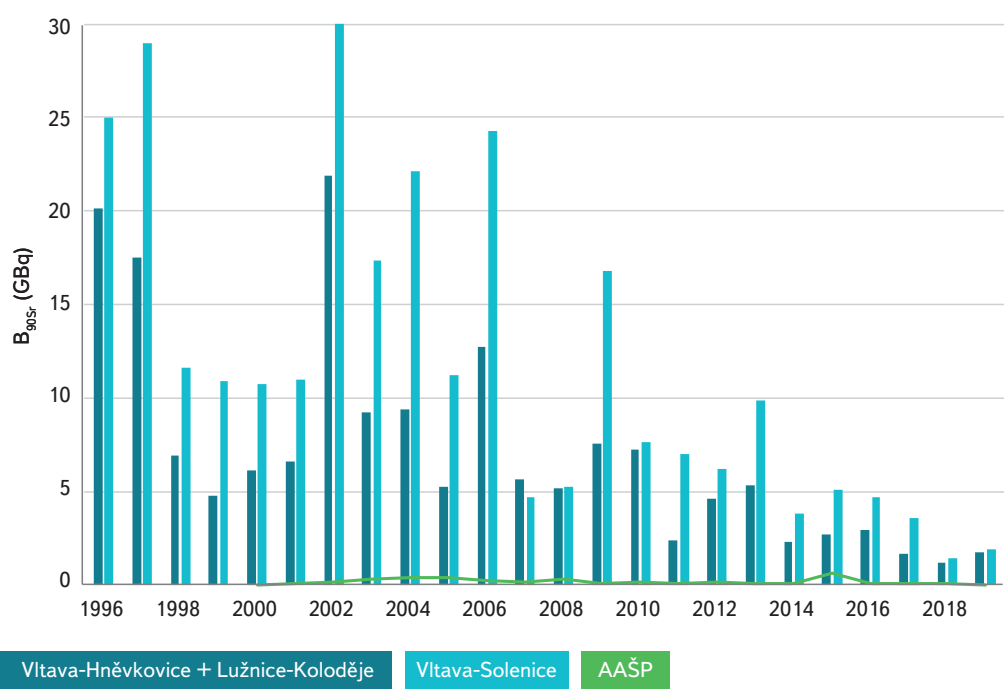

Obr. 6. Vývoj antropogenního pozadí ${ }^{90} \mathrm{Sr}$ v místě zaústění odpadních vod vyjádřeného jako součet bilance ${ }^{90} \mathrm{Sr} v$ profilech VItava-Hněvkovice a Lužnice-Koloděje, bilance ${ }^{90} \mathrm{Sr}$ v ovlivněném profilu VItava-Solenice a výpustí AAŠP podle ČEZ, a. S., JETE $[8,9]$ Fig. 6. Temporal changes of activity ${ }^{90} \mathrm{Sr}$ balances (artificial bacground of ${ }^{90} \mathrm{Sr}$, calculated as sum of ${ }^{90} \mathrm{Sr}$ balances in the VItava River at Hněvkovice and the Lužnice River at Koloděje), balance at effected in the VItava River at Solenice and discharges of activation and fission products according ČEZ, a. S., JETE $[8,9]$

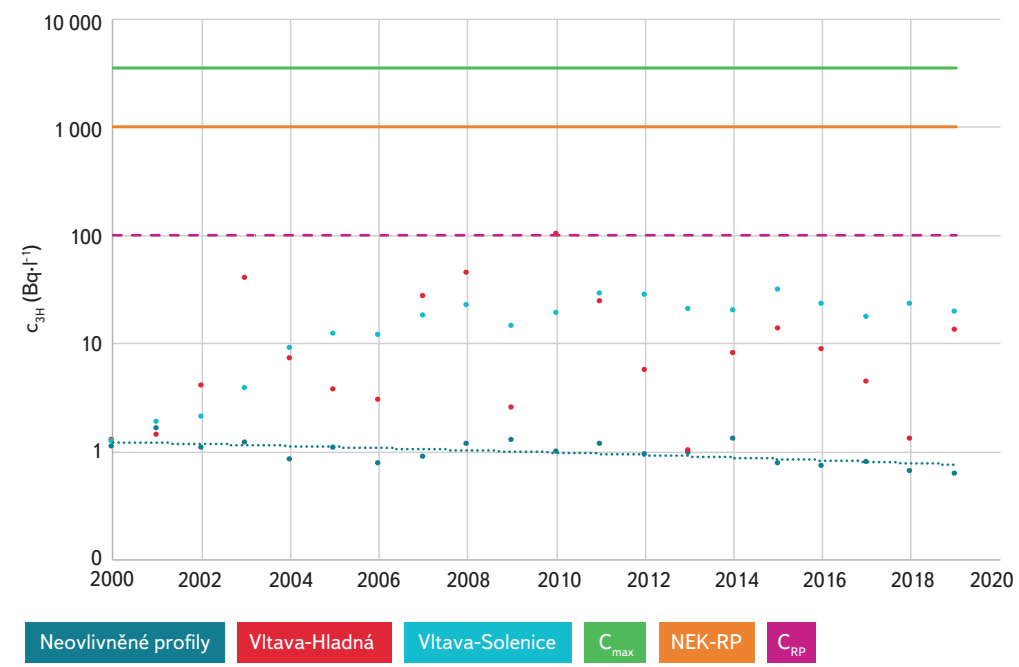

Obr. 7. Vývoj objemové aktivity ${ }^{3} \mathrm{H}\left(\mathrm{C}_{3 \mathrm{H}}\right)$ v profilech neovlivněných výpustmi z JE Temelín, $\checkmark$ ovlivněných profilech VItava-Hladná a Solenice a hodnoty prípustného znečištění $C_{\max }$ a $C_{R P}$ a NEK-RP podle NV 401/2015 Sb. [23]

Fig. 7. Temporal changes of ${ }^{3} \mathrm{H}$ concentration $\left(\mathrm{C}_{3 \mathrm{H}}\right)$ in profiles not effected by discharges of wastewaters from the NPP Temelín and in VItava River at Solenice and Hladná (effected profiles) and value of permissible pollution $C_{\max }$ and $C_{R P}$ and environmental quality standard-annual average NEK-RP according NV 401/2015 Sb. [23]

a přirozeného původu) v místě zaústění odpadních vod bylo 1,5 GBq·r¹. Bilance ${ }^{3} \mathrm{H}$ v ovlivněných profilech je významně vyšší. Jak bylo uvedeno výše, objemové aktivity ${ }^{3} \mathrm{H}$ v profilu VItava-Hladná, jsou ve velkém rozpětí, to se týká i vypočtených bilancí (v období 2003-2019: 1-230 TBq·r', průměrně 30 TBq $\cdot r^{-1}$ ), které př́liš̌ neodpovídají uváděným výpustem ${ }^{3} \mathrm{H}[8,9]$. Je to způsobeno především malou vzdáleností tohoto profilu od zaústění odpadních vod z JE Temelín (cca 4 km) a diskontinuálním vypouštěním odpadních vod. Vzhledem k četnosti vzorkování (4× ročně) není takto vypočtená roční průměrná hodnota v tomto profilu 
př́liš vypovídající. V profilu Vltava-Solenice, po promíchání vod ve vodní nádrži Orlík, je už výpovědní hodnota větší a vypočtená bilance (v období 2003-2019: 8-79 TBq.r' , průměrně 43 TBq·r'r') odpovídá výpustem tritia udávaných provozovatelem (v období 2003-2019: 23-64 TBq·r', průměrně 42 TBq/r) [8, 9], jak je zřejmé i z obr. 8.

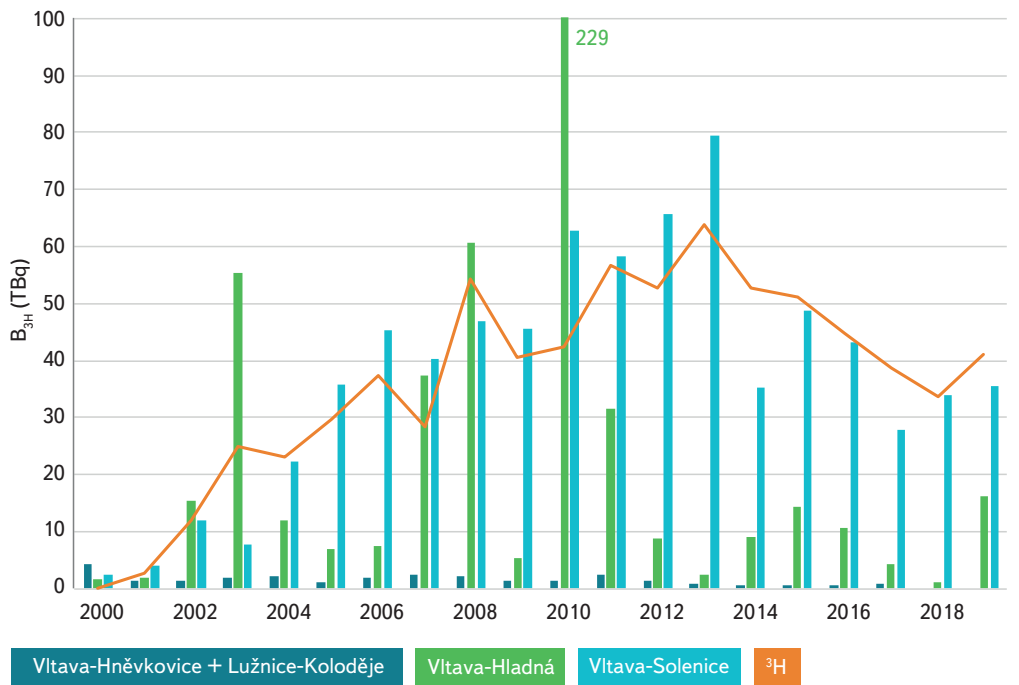

Obr. 8. Vývoj pozadí ${ }^{3} \mathrm{H}$ v místě zaústění odpadních vod vyjádřeného jako součet bilance ${ }^{3} \mathrm{H}$ v profilech VItava-Hněvkovice a Lužnice-Koloděje, bilance ${ }^{3} \mathrm{H}$ v ovlivněných profilech VItava-Hladná a Solenice a výpustí ${ }^{3} \mathrm{H}$ podle ČEZ, a. S., JETE $[8,9]$ Fig. 8. Temporal changes of activity ${ }^{3} \mathrm{H}$ balances (artificial + natural bacground of ${ }^{3} \mathrm{H}$ in the VItava River at Hněvkovice and the Lužnice River at Koloděje), the Vltava River at Solenice and discharges of ${ }^{3} \mathrm{H}$ according ČEZ, a. S., JETE $[8,9]$

Jak už bylo uvedeno dřive, v profilech neovlivněných provozem JE Temelín byl pozorován mírný pokles ročních průměrných hodnot v celém sledovaném období s výjimkou profilu Otava-Topělec, kde tento pokles nebyl statisticky významný. Vyhodnocené efektivní poločasy byly delší než 20 r. To je více než je poločas přeměny ${ }^{3} \mathrm{H} 12,3 \mathrm{r}$ [6]. Je to dáno tím, že obsah tritia $v$ atmosféře po testech jaderných zbraní $v$ atmosfére $v$ minulém století už je velmi malý a úroveň tritia se postupně blíži přirozenému pozadí, které je $v$ ČR odhadováno na $0,6 \mathrm{~Bq} \cdot \mathrm{l}^{-1}[24,25]$. Příspěvek tritia z produkce jaderných elektráren jinde ve světě i u nás je na našem území velmi malý a v rámci celkových nejistot jej můžeme zanedbat [25].

\section{ZÁVĚR}

Byl sledován vývoj radionuklidu ${ }^{3} \mathrm{H},{ }^{137} \mathrm{Cs}$ a ${ }^{90} \mathrm{Sr}$ v povrchových vodách v okolí JE Temelín. Téměř třicetileté sledování zahrnuje období před a po uvedení elektrárny do provozu, kdy byly sledovány profily nad i pod zaústěním odpadních vod. Na základě těchto výsledků je proto možné hodnotit vliv elektrárny na obsah těchto radionuklidů ve sledovaných profilech.

$\checkmark$ prípadě ${ }^{137} \mathrm{C} s$ a ${ }^{90} \mathrm{Sr}$ byl pozorován trvalý pokles objemových aktivit na všech hodnocených profilech - neovlivněných i ovlivněných výpustmi z JE Temelín. Zatímco na počátku sledovaného období byly pozorované roční průměrné objemové aktivity až desítky $\mathrm{mBq} \cdot \mathrm{l}^{-1}$, na konci toho období byla většina hodnot menší než $\mathrm{C}_{\mathrm{N},{ }^{\prime}} \mathrm{tj} .<0,5 \mathrm{mBq} \cdot \mathrm{l}^{-1}\left({ }^{137} \mathrm{Cs}\right)$, resp. $<2 \mathrm{mBq} \cdot \mathrm{l}^{-1}\left({ }^{90} \mathrm{Sr}\right)$. Byly vypočteny roční bilance těchto radionuklidů a porovnány s údaji provozovatele ČEZ, a. S., JE Temelín o výpustech AAŠP. Na základě bilancí v profilech nad zaústěním odpadních vod - VItava-Hněvkovice a Lužnice-Koloděje v období 2003-2019 bylo odvozeno průměrné „pozadí" roční bilance aktivity ${ }^{137} \mathrm{Cs} 1,7 \mathrm{GBq} \cdot \mathrm{r}^{-1}$ a ${ }^{90} \mathrm{Sr} 5,1 \mathrm{GBq} \cdot \mathrm{r}^{1}$, zatímco průměrné roční výpusti AAŠP nepřesáhly $0,2 \mathrm{GBq} \cdot r^{r}$. Současné pozadí ${ }^{137} \mathrm{Cs}$ a ${ }^{90} \mathrm{Sr}$, které pochází z reziduální kontaminace po testech jaderných zbraní a černobylské havárii, zatím zcela překrývá roční kapalné výpusti JE Temelín pro AAŠP.

U tritia byl zaznamenán významný rozdíl ve vývoji objemových aktivit na ovlivněných a neovlivněných profilech. Na neovlivněných profilech byl pozorován mírný, ale trvalý pokles zjištěných aktivit. Na konci hodnoceného období (2019) byla většina hodnot $<\mathrm{C}_{\mathrm{ND}}$, průměrně $<1 \mathrm{~Bq} \cdot \cdot^{-1}$. Reziduální obsah tritia $\checkmark$ atmosféře po testech jaderných zbraní $v$ minulém století už je velmi malý a úroveň objemové aktivity tritia v povrchových vodách se postupně blíži prírozenému pozadí (cca 0,6 Bq. $\left.\left.\right|^{-1}\right)$. V profilech ovlivněných provozem JE Temelín byl po spuštění elektrárny pozorován postupný nárůst jak sledovaných objemových aktivit, tak i vypočtených ročních bilancí tritia. Bilance pozadí tritia př́rodního i antropogenního původu v místě výpustí odpovídá 1,5 TBq·r ${ }^{-1}$, průměrná bilance $v$ profilu VItava-Solenice v období 2003-2019 byla 43 TBq. $r^{1}$ a průměrná roční výpust ${ }^{3} \mathrm{H}$ v hodnoceném období byla $42 \mathrm{TBq} \cdot \mathrm{r}^{-1}$.

Souhrnně lze konstatovat, že provoz dvou bloků elektrárny s výkonem 2000, resp. 2164 MWe, nevedl k překročení hodnot prípustného znečištění ani norem environmentální kvality podle nařízení vlády 401/2015 Sb. v ukazatelích radioaktivních látek.

Tabulka 1. Prehled vyhodnocených efektivních poločasů $T_{\text {ef }}$ hodnocených radionuklidů v povrchové vodè

Table 1. Overview of evaluated effective half lifes in surface water

\begin{tabular}{|c|c|c|c|c|c|c|c|}
\hline \multirow[t]{2}{*}{ Radionuklid } & \multirow{2}{*}{$\begin{array}{l}\text { Hodnocené } \\
\text { období }\end{array}$} & $\begin{array}{l}\text { Vltava- } \\
\text {-Hněvkovice }\end{array}$ & $\begin{array}{l}\text { Otava- } \\
\text {-Topělec }\end{array}$ & $\begin{array}{l}\text { Lužnice- } \\
\text {-Koloděje }\end{array}$ & $\begin{array}{l}\text { Neovlivněné } \\
\text { profily }\end{array}$ & $\begin{array}{l}\text { Vltava- } \\
\text {-Hladná }\end{array}$ & $\begin{array}{l}\text { Vltava- } \\
\text {-Solenice }\end{array}$ \\
\hline & & \multicolumn{6}{|c|}{$T_{\text {ef }}(r)$} \\
\hline \multirow{2}{*}{${ }^{137} \mathrm{Cs}$} & 1990-1994 & $1,6 \pm 0,6$ & $1,1 \pm 0,4$ & $2,8 \pm 2,1$ & $1,3 \pm 0,2$ & - & $1,4 \pm 0,4$ \\
\hline & 1995-2019 & $9,4 \pm 1,1$ & $12,3 \pm 2,5$ & $12,4 \pm 1,5$ & $11,5 \pm 1,3$ & $\left.11,8 \pm 2,2^{*}\right)$ & $12,2 \pm 3,0$ \\
\hline${ }^{90} \mathrm{Sr}$ & 1993-2019 & $9,7 \pm 1,1$ & $11,2 \pm 1,3$ & $8,7 \pm 1,0$ & $10,3 \pm 0,9$ & $7,9 \pm 0,9$ & $9,8 \pm 1,3$ \\
\hline${ }^{3} \mathrm{H}$ & $2000-2019$ & $23,6 \pm 6,6$ & - & $28,2 \pm 5,2$ & $27,6 \pm 6,4$ & - & \\
\hline
\end{tabular}




\section{Literatura}

[1] HANSLÍK, E. Výzkum vlivu jaderně-energetických zar̆izení na životní prostředi. Zpráva, Praha: VÚV TGM 1995

[2] HANSLÍK, E. Výzkum vlivu jaderně-energeticjých zařizeni na životni prostředí. Zpráva, Praha: VúV TGM, 1998

[3] MYNÁŘ, P. a kol. Program sledováni a hodnocení vivů jaderné elektrárny Temelín na životní prostředí. Brno: ČEZ, a. S., INVESTprojekt, spol. s r. O., 1999.

[4] ČEZ, a. s. Jaderná elektrárna Temelín. [Online]. Dostupné z: https://www.cez.cz/cs/o-cez/vyrobnizdroje/jaderna-energetika/jaderna-energetika-v-ceske-republice/ete. [Přístup získán 28. 4. 2020].

[5] ČEZ, a. s. Nový jaderný zdroj v lokalitě Temelín. [Online]. Dostupné z: https://www.cez.cz/cs/ocez/vyrobni-zdroje/jaderna-energetika/jaderna-energetika-v-ceske-republice/nove-jadernezdroje/novy-temelin. [Přístup získán 30. 4. 2020].

[6] ROZANSKI, K. and GROENING, M. Tritium assay in water samples using elektrolytic enrichment and liquid scintilation spectrometry. Quantifying uncertainty in nuclear analytical measurements, IAEA 2004, p. 195-217.

[7] LEDERER, C.M. and SHIRLEY, V.S. Table of isotopes. New York: J. Willey\&Sons, $7^{\text {th }}$ ed., 1978.

[8] FECHTNEROVÁ, M. Zpráva o životním prostředíza rok2001-2005. ČEZ, a. s., Jaderná elktrárna Temelín, 2002-2006.

[9] LYSÁČEK, F. Zpráva o životním prostředi 2006-2019. ČEZ, a. S., Jaderná elektrárna Temelín, 2007-2020.

[10] HANSLÍK, E., MAREŠOVÁ, D., JURANOVÁ, E. a SEDLÁŘOVÁ, B. Změny obsahu radionuklidi̊ v povrchové vodě v okolí Jaderné elektrárny Temelín v období 1990-2016. VTEl, 2016, Č. 2, s. 18-23. ISSN 0322-8916.

[11] HANSL [KK, E JEDINÁKOVÁ-KŘIŽOVÁ, V IVANOVOVÁ, D, KALINOVÁ, E SEDLÁŘOVÁ, B, and ŠIMONEK, P. Observed half-lives of ${ }^{3} \mathrm{H},{ }^{90} \mathrm{Sr}$ and ${ }^{137} \mathrm{C}$ s in hydrosphere in the VItava River basin (Bohemia). Journal of Environmental Radioactivity, 2005 (81), 2-3, p. 307-320.

[12] HANSLÍK, E., IVANOVOVÁ, D., JEDINÁKOVÁ-KŘIŽOOVÁ, V., JURANOVÁ, E. a ŠIMONEK, P. Concentration of radionuclides in hydrosphere affected by Temelín nuclear power plant in Czech Republic. Journa of Environmental Radioactivity, 2009 (100), 7, p. 558-563.

[13] IVANOVOVÁ, D. a HANSLÍK, E. Vliv odpadních vod z JE Temelín na obsah tritia ve Vltavě a Labi do roku 2008. VTEl, 2009, roč. 51, č. 6, s. 1-5. ISSN 0322-8916.

[14] ČSN EN ISO 5667-1. Jakost vod: Odběr vzorků - Část 1: Návod pro návrh programu odběru vzorkü a pro způsoby odběru vzorkü, ČNI, 2007.

[15] ČSN EN ISO 5667-3. Kvalita vod: Odběr vzorkü - Část 3: Konzervace vzorků vod a manipulace s nimi ČAS, 2019

[16] ČSN ISO 5667-4. Kvalita vod: Odběr vzorkü - Cást 4: Návod pro odběr vzorků z jezer a vodních nádržı̆ ČAS, 2018.

[17] ČSN EN ISO 5667-6. Kvalita vod: Odběr vzorkü - Část 6: Návod pro odběr vzorků z řek a potokư, ÚNMZ, 2017.

[18] ČSN EN ISO 9698. Kvalita vod: Tritium - Kapalinová scintilačníměřici metoda, ČAS, 2019.

[19] ČSN EN ISO 10703. Jakost vod: Stanovení objemové aktivity radionuklidü - Metoda spektrometrie záren gama s vysokým rozlišením, ČNI, 2008.

[20] MŽP. Metodická príručka pro stanovení ukazatelů znečištěnívod. Praha: MŽP, 1993.

[21] NESMĚRÁK, I. K problematice náhrad hodnot pod mezí stanovitelnosti pr̆i chemických analýzách a monitorováni stavu vod, Vliv náhrady hodnot pod mezi stanovitelnosti polovinou meze stanovitelnosti na statistické charakteristiky souborü hodnot. Výzkum pro praxi 57, Praha, VÚV TGM, 2009.

[22] SMITH, J.T. and BERESFORD, N.A. Chernobyl-Catastrophe and Consequences. New York: Springer, 2005

[23] Nařízení vlády č. 401/2015 Sb., o ukazatelích a hodnotách prípustného znečištění povrchových vod a odpadních vod, náležitostech povolení k vypouštění odpadních vod do vod povrchových a do kanalizací a o citlivých oblastech.

[24] GAT, J.R., MOOK, W.G., and MEIJER, H.A.J. Environmental Isotopes ant he Hydrological Cycle, Principles and Applications. Atmospheric Water, Vol. 2, IAEA, 2001.

[25] MAREŠOVÁ, D., HANSLIKK, E., JURANOVÁ, E. a SELDÁŘOVÁ, B. Stanovení velmi nízkých objemových aktivit tritia pro potřeby využití triti jako stopovače. VTEI, 2018, roč. 60, č. 4, s. 4-8. ISSN 0322-8916.

\section{Autoři}

RNDr. Diana Marešová, Ph.D.

凶diana.maresova@vuv.cz

ORCID: 0000-0001-9047-6747

Ing. Eva Juranová

凶eva.juranova@vuv.cz

ORCID: 0000-0001-9021-7307

Ing. Barbora Sedlářová

$凶$ barbora.sedlarova@vuv.cz

ORCID: 0000-0003-0271-8473

Výzkumný ústav vodohospodářský T. G. Masaryka, v. v. i.

Přispěvek prošel lektorským řízením.

DOI: 10.46555/VTEI.2020.05.005

\section{IMPACT OF THE NUCLEAR POWER PLANT TEMELÍN ON CONCENTRATION OF SELECTED RADIONUCLIDES IN THE HYDROSPHERE}

\section{MARESOVA, D.; JURANOVA, E.; SEDLAROVA, B.}

TGM Water Research Institute, p.r.i.

Keywords: radionuclides - tritium - caesium 137 strontium 90 - surface water - wastewater

The paper presents results and interpretation of long-term monitoring of occurrence and behaviour of selected radionuclides in the vicinity of the Temelín Nuclear Power Plant (Temelin NPP). Temporal and spatial changes in concentrations of tritium, strontium 90 and caesium 137 were assessed. Concentrations of radionuclides were evaluated in surface water both affected and unaffected by waste water discharges from the Temelín NPP before and during the operation of the plant. The assessment included residual contamination from atmospheric tests of nuclear weapons in the last century and the Chernobyl accident in 1986. Results of long-term monitoring (1990-2019) were used for derivation of effective ecological half-lives. Possible impact of waste waters discharged from the Temelín NPP on tritium, caesium 137 and strontium 90 concentrations in the Vltava River was assessed by using data observed over the period of 2001-2019. A decline in caesium 137 and strontium 90 concentrations was observed in all of the monitored sites. A very slow decline in tritium concentration at unaffected sites was observed. At sites downstream from the power plant the ${ }^{3} \mathrm{H}$ concentrations were significantly higher, an evident impact of the power plant operation. It can be stated, that operation of the Temelín NPP with two reactors with installed output $2164 \mathrm{MWe}$ did not cause exceeding the values of permissible pollution and environmental quality standards according Government Regulation 401/2015 Col. 